\title{
Verwerking van leasecontracten in de jaarrekening
}

\author{
J.H. Jager en H.B. van Veen
}

\section{Inleiding}

Momenteel is binnen de financiële verslaggeving een discussie gaande over de verwerking van leasecontracten in de jaarrekening. Gebruikers van de jaarrekening uiten hun ontevredenheid over de informatie die op basis van de bestaande wet- en regelgeving in de jaarrekening over leasecontracten wordt verstrekt. Ondernemingen zijn nu nog in staat om leasecontracten zodanig op te stellen, dat de lease als 'operational lease' wordt geclassificeerd en daarmee niet op de balans van de lessee verschijnt. De discussie spitst zich dan ook toe op de vraag of het maken van een onderscheid tussen operational en financial leasing wel de juiste classificatie is. Onder de naam G4+1-organisaties hebben de regelgevende instanties van Australië, Canada, Nieuw-Zeeland, het Verenigd Koninkrijk en de Verenigde Staten en het International Accounting Standards Committee (IASC) twee rapporten gepubliceerd, waarin een oplossing voor dit probleem wordt gezocht. De G4+1-organisaties stellen in dit kader een 'asset en liability'-benadering voor. Binnen de 'asset en liability'-benadering wordt de verwerking van leasecontracten in de jaarrekening gebaseerd op het Stramien voor de opstelling en vormgeving van jaarrekeningen (hierna genoemd: Stramien). In het Stramien zijn de definities en verwerkingscriteria van een actief en een passief opgenomen. Deze definities en verwerkingscriteria vormen de basis voor de verwerking van leasecontracten in de jaarrekening binnen de 'asset en liability'-benadering. Indien in de weten regelgeving wordt overgestapt naar de 'asset en liability'-benadering voor de verwerking van leasecontracten in de jaarrekening, zal dit grote gevolgen hebben voor de verslaggevingspraktijk en voor leasemaatschappijen en bedrijven die gebruikmaken van leasing.

In dit artikel zullen wij in eerste instantie ingaan op de momenteel gehanteerde 'risks en rewards'- benadering. Binnen deze benadering is het onderscheid tussen operational en financial leasing bepalend voor de verwerking van leasecontracten in de jaarrekening. Wij zullen de problemen die bij de toepassing van de 'risks en rewards'-benadering optreden, bespreken. Vervolgens komt de nieuwe 'asset en liability'-benadering aan de orde. Eerst zal deze benadering worden uitgewerkt om vervolgens uitgebreid de verwerking van extra afspraken in leasecontracten op basis van deze benadering te bespreken. Tot slot zullen de mogelijke gevolgen van toepassing van de 'asset en liability'-benadering voor de praktijk aan bod komen.

Het is niet de bedoeling om in dit artikel op alle verschillende benaderingen van verwerking van leasecontracten in de jaarrekening in te gaan. Binnen dit artikel komen uitsluitend de 'risks en rewards'-benadering en de 'asset en liability'benadering aan bod, omdat de discussie binnen de internationale verslaggeving zich op deze twee benaderingen concentreert. Daarnaast is het met betrekking tot de verwerking van extra afspraken binnen leasecontracten in de jaarrekening, niet de bedoeling te komen tot een limitatieve opsomming en behandeling van alle mogelijke afspraken. Ook zal in dit artikel niet worden ingegaan op contracten die vergelijkbaar zijn met leasecontracten, zoals bijvoorbeeld servicecontracten.

\section{De 'risks en rewards'-benadering}

Binnen de 'risks en rewards'-benadering is de verwerking van leasecontracten in de jaarrekening

J.H. Jager en H.B. van Veen zijn als studenten Accountancy verbonden aan de Erasmus Universiteit Rotterdam. H.B. van Veen is daarnaast als docent Economie verbonden aan het Einstein Lyceum in Hoogvliet. 
afhankelijk van de vraag of de risico's en beloningen voortvloeiend uit het in eigendom hebben van het actief vrijwel geheel overgaan van de lessor op de lessee. Indien de risico's en beloningen vrijwel geheel overgaan op de lessee, dan is er sprake van een financial lease. Indien dit bij een leasecontract niet het geval is, dan is er sprake van een operational lease. Het onderscheid tussen financial en operational leases vormt de basis voor vrijwel alle bestaande wet- en regelgeving voor verwerking van leasecontracten in de jaarrekening.

Wet- en regelgevende instanties maken het onderscheid tussen financial en operational leases vaak concreter door diverse indicatiecriteria te hanteren om leasecontracten beter te kunnen classificeren. Een veelgebruikt indicatiecriterium hierbij is bijvoorbeeld dat indien binnen een leasecontract de contante waarde van alle door de lessee in verband met de lease te verrichten betalingen $90 \%$ of meer van de waarde van het leaseobject bij aanvang van de lease bedraagt, er waarschijnlijk sprake is van een financial lease.

\subsection{Verwerking van financial en operational leases}

Het onderscheid tussen financial en operational leasing is aldus bepalend voor de manier waarop leasecontracten in de jaarrekening worden verwerkt. Volgens huidige verslaggevingsstandaarden dient de lessee leasecontracten als volgt in de jaarrekening op te nemen:

- In geval van een financial lease worden activa en passiva op de balans opgenomen. Op basis van de meeste standaarden gebeurt dit tegen de contante waarde van de leasetermijnen; het geleaste actief wordt afgeschreven in de perioden waarin de lessee van het in eigendom hebben van het actief profiteert. De leaseverplichting (passief), wordt afgeboekt op het moment van de betaling van de leasetermijnen.

- In geval van een operational lease neemt de lessee alleen de kosten van de lease op in zijn resultatenrekening. Er verschijnen geen activa en passiva op de balans van de lessee.

Volgens huidige verslaggevingsstandaarden dient de lessor leasecontracten als volgt in de jaarrekening op te nemen:

- In geval van een financial lease neemt de lessor de contante waarde van de in de toekomst te ontvangen leasetermijnen van de lessee op. Het verschil tussen deze waarde en de boekwaarde van het geleaste actief, die de lessor bij het afsluiten van het contract afboekt, verantwoordt de lessor als handelswinst in zijn resultatenrekening.
- In geval van een operational lease activeert de lessor het geleaste actief op zijn balans en dient hij het actief stelselmatig af te schrijven over de verwachte gebruiksduur. De ontvangen leasetermijnen dienen als baten in de resultatenrekening te worden opgenomen.

\subsection{Problemen bij de 'risks en rewards'- benadering}

De in de wet- en regelgeving gehanteerde 'risks en rewards'-benadering heeft in de financiële-verslaggevingspraktijk tot verschillende ongewenste effecten geleid. De 'risks en rewards'-benadering biedt, via de verwerking die geldt voor operational leasecontracten, de mogelijkheid tot off-balance sheet-financiering van geleaste activa. Veel bedrijven proberen van deze mogelijkheid gebruik te maken, omdat dit de liquiditeits- en de solvabiliteitskengetallen, die op basis van de balans worden bepaald, ten goede komt.

Bedrijven proberen op verschillende manieren hun leasecontracten als 'operational leases' te laten classificeren. Bedrijven grijpen hiervoor de in de regelgeving gebruikte indicatiecriteria aan, om leasecontracten zodanig af te sluiten dat de criteria voor classificatie als financial lease net niet worden gehaald. Bijvoorbeeld met betrekking tot het indicatiecriterium betreffende de hoogte van de contante waarde van de leasetermijnen. De grens ligt bij dit criterium op $90 \%$ van de waarde van het geleaste actief, waarna in de praktijk het leasecontract zodanig wordt opgesteld dat de contante waarde van de leasetermijnen $88 \%$ bedraagt (Tweedie, 1999). Op deze manier wordt de lease geclassificeerd als operational lease en derhalve niet op de balans van de lessee verantwoord, terwijl de lease niet wezenlijk verschilt van een financial lease.

Uit voorgaand voorbeeld blijkt dat het onderscheid tussen financial en operational leasecontracten heel klein kan zijn. Dit onderscheid kan echter wel grote gevolgen hebben op de verwerking van leasecontracten in de jaarrekening. Zowel de hoogte van de activa en passiva op de balans, als de hoogte van de kosten in de resultatenrekening van de lessee worden erdoor beïnvloed. De mogelijkheden die bedrijven zodoende hebben om de verwerking van leasecontracten in de jaarrekening met kleine aanpassingen te beïnvloeden, vertekent de getrouwe weergave die de jaarrekening dient te geven. Het nut van de financiële jaarrekening voor gebruikers daalt hierdoor, crediteuren kunnen bijvoorbeeld de liquiditeit van een onderneming minder goed inschatten.

Een mogelijkheid om dit probleem op te los- 
sen, zou kunnen zijn om de grenzen die in de verschillende criteria worden genoemd, te verlagen. De contante waarde van de leasetermijnen zou bijvoorbeeld kunnen worden verlaagd tot minimaal $80 \%$ van de waarde van het geleaste actief (Tweedie, 1999). Dit zou in eerste instantie kunnen leiden tot een vergroting van het aantal financial leases. Op de lange termijn zullen de leasecontracten echter weer zodanig worden opgesteld dat de leases weer onder de nieuw gestelde grenzen zullen uitkomen en de lease zodoende weer als operational lease zal worden geclassificeerd.

\section{De 'asset en liability'-benadering}

Het doel van de 'asset en liability'-benadering is om te komen tot een op het Stramien gebaseerde manier van het verwerken van leasecontracten in de jaarrekening. In de eerste plaats wordt nagegaan of een potentiële post, die ontstaat op basis van een leasecontract, voldoet aan de definitie van een actief of een passief. Om vervolgens voor verwerking in aanmerking te komen moet deze post voldoen aan de verwerkingscriteria, die in het Stramien worden genoemd. Het onderscheid tussen operational en financial leasing speelt hierbij geen rol meer'.

\subsection{Definiëring}

In het Stramien wordt een actief gedefinieerd als 'een uit gebeurtenissen in het verleden voortgekomen middel, waarover de onderneming de beschikkingsmacht heeft en waaruit in de toekomst naar verwachting economische voordelen naar de onderneming zullen vloeien' (Stramien, par. 49). De definitie van een actief leidt in verband met een leasecontract tot activa voor zowel de lessee als de lessor. De lessee heeft namelijk de beschikkingsmacht over de economische voordelen, die voortkomen uit het in gebruik hebben van het geleaste goed gedurende de leaseperiode. De lessor heeft de beschikkingsmacht over de economische voordelen, die voortkomen uit het recht dat hij heeft op de te ontvangen leasetermijnen. De lessor heeft daarnaast het recht op de economische voordelen, die het actief na afloop van de leaseperiode in zich bergt. Zowel de lessee als de lessor bezit binnen de nieuwe benadering op deze manier activa die voor hen ontstaan op basis van het leasecontract.

In het Stramien wordt een passief gedefinieerd als 'een bestaande verplichting van de onderneming, die voortkomt uit gebeurtenissen in het verleden, waarvan de afwikkeling naar verwachting resulteert in een uitstroom uit de onderneming van middelen die economische voordelen in zich ber- gen' (Stramien, par. 49). Een afgesloten leasecontract, een transactie in het verleden, leidt tot een verplichting voor de lessee om in de toekomst economische voordelen (leasetermijnen) aan de lessor over te dragen. Deze verplichting leidt voor de lessee tot een passief.

\subsection{Verwerking}

Volgens het Stramien 'wordt een actief in de balans verwerkt wanneer het waarschijnlijk is dat de toekomstige economische voordelen aan de onderneming zullen toevloeien en het actief een kostprijs of waarde heeft waarvan de omvang op betrouwbare wijze kan worden vastgesteld' (Stramien, par. 89). In geval van een leasecontract zullen de economische voordelen naar alle waarschijnlijkheid naar de lessee respectievelijk de lessor toevloeien. In het leasecontract is namelijk overeengekomen dat de lessee de lessor gedurende de contractsduur leasetermijnen zal betalen. In ruil voor deze betalingen heeft de lessee het recht op de economische voordelen die het gebruik van het geleaste actief met zich meebrengt. Het afsluiten van het leasecontract leidt er aldus toe dat er waarschijnlijk economische voordelen aan de lessee dan wel lessor zullen toevloeien. Ten slotte is het ook waarschijnlijk dat na afloop van het leasecontract het geleaste actief weer ter beschikking staat van de lessor en dat aldus de lessor het recht heeft op de economische voordelen die gedurende de rest van de economische gebruiksduur van het actief ontstaan.

De kostprijzen of waarden van deze activa voor lessees en lessors zijn betrouwbaar vast te stellen, omdat de overeengekomen te betalen leasetermijnen en de overeengekomen contractsduur een goede uitgangspositie vormen om de kostprijzen of waarden te bepalen. De activa die ontstaan op basis van het leasecontract voldoen aan de verwerkingscriteria in het Stramien en dienen derhalve in de jaarrekening te worden verwerkt.

Volgens het Stramien 'wordt een passief in de balans verwerkt wanneer het waarschijnlijk is dat de afwikkeling van een bestaande verplichting gepaard zal gaan met een uitstroom van middelen die economische voordelen in zich bergen en de omvang van het bedrag waartegen de afwikkeling zal plaatsvinden op betrouwbare wijze kan worden vastgesteld' (Stramien, par. 91).

Bij het afsluiten van een leasecontract ontstaat er voor de lessee een verplichting om middelen die economische voordelen in zich bergen (geld), te betalen aan de lessor in de vorm van leasetermijnen. De hoogte van deze leasetermijnen wordt in het leasecontract overeengekomen en vormt zo 
een betrouwbare basis om de omvang van de verplichting te bepalen. Op deze manier voldoen de te betalen leasetermijnen aan de verwerkingscriteria voor een passief en dus dienen deze leasetermijnen als een passief in de jaarrekening te worden verwerkt.

\subsection{Waardering}

Het gebruiksrecht, het actief, en de te betalen leasetermijnen, het passief van de lessee zal de lessee op de balans moeten opnemen tegen de contante waarde van de leasetermijnen. De leasetermijnen worden verdisconteerd tegen de impliciete rentevoet, die uit het leasecontract blijkt. De lessee zal het actief vervolgens stelselmatig moeten afschrijven. De te betalen leasetermijnen zullen in de loop van de tijd worden afgeboekt naar aanleiding van het betalen van het in de leasetermijnen begrepen aflossingsdeel. Het in de leasetermijnen begrepen interestbestanddeel zal ten laste van het resultaat moeten worden gebracht.

De lessor zal het recht op de te ontvangen leasetermijnen activeren tegen de contante waarde van de leasetermijnen. De betaling van de aflossing door de lessee zal leiden tot het afboeken van dit recht. De betaling van het interestgedeelte door de lessee zal ten gunste van het resultaat worden gebracht. De lessor heeft daarnaast het recht op de restwaarde van het geleaste actief na afloop van het leasecontract. De lessor zal dit recht in zijn balans activeren tegen de verwachte waarde van het actief na de leaseperiode. Op dit recht wordt niet afgeschreven, wel wordt jaarlijks beoordeeld of de verwachte waarde nog reëel is. Indien dat niet het geval is, zal het verschil in de resultatenrekening worden verwerkt.

Het apart opnemen van beide rechten in de balans van de lessor leidt tot een duidelijkere weergave van de financiële positie van de lessor en de risico's die de lessor bij deze rechten loopt. Bij het recht op leasetermijnen behoort bijvoorbeeld het risico dat er niet wordt betaald, terwijl bij het recht op de restwaarde het risico van economische veroudering een belangrijke rol speelt.

\subsection{Een voorbeeld}

Veronderstel dat een lessor en een lessee een leasecontract afsluiten voor vijf jaar. Afgesproken wordt dat de lessee een machine least van de lessor tegen een jaarlijkse leasetermijn van 13.189,87 euro, die jaarlijks achteraf wordt betaald. In het leasecontract wordt een rentepercentage van $10 \%$ gehanteerd. De lessee zal de machine na vijf jaar aan de lessor retourneren. De machine heeft nog een economische levensduur van acht jaar (geen restwaarde), er wordt door de lessor lineair afgeschreven, de machine is net aangeschaft voor 80.000 euro. De lessee schrijft over de geleaste activa lineair af. $\mathrm{Na}$ een jaar van de leaseperiode blijkt dat de machine door economische veroudering nog maar 6,5 jaar te gebruiken zal zijn.

De situatie vóór het afsluiten van het leasecontract ${ }^{2}$ :

$\overline{\frac{\text { Balans Lessor (in euro) }}{\text { Machine } 80.000}} \frac{}{\text { Balans Lessee (in euro) }}$

De situatie direct na het afsluiten van het leasecontract:

\begin{tabular}{l|rr}
\hline $\begin{array}{l}\text { Balans Lessor (in euro) } \\
\begin{array}{l}\text { Restwaarde } \\
\text { geleaste }\end{array} \\
\text { machines } 30.000\end{array}$ & $\begin{array}{r}\text { Balans Lessee (in euro) } \\
\text { Geleaste activa }\end{array}$ & $\begin{array}{l}\text { Leasever- } \\
\text { plichtingen }\end{array}$ \\
$\begin{array}{r}\text { Leasedebiteuren } \\
50.000\end{array}$ & & 50.000 \\
& & \\
& &
\end{tabular}

In bovenstaande balansen heeft de verwerking van het afsluiten van het leasecontract reeds plaatsgevonden. Bij de lessor is het deel van de machine dat de lessor ter beschikking heeft gesteld aan de lessee, afgeboekt van de machine. In ruil voor het ter beschikking stellen van de machine aan de lessee heeft de lessor een vordering op de lessee van vijf jaarlijkse leasetermijnen. De contante waarde van deze leasetermijnen is 50.000 euro en deze wordt opgenomen onder de post leasedebiteuren. De lessee heeft het gebruiksrecht op de geleaste machine geactiveerd en de te betalen leasetermijnen gepassiveerd voor de contante waarde van de leasetermijnen à $13.189,87$ euro per jaar (50.000 euro in totaal). De lessee activeert het gebruiksrecht, omdat dit gebruiksrecht een actief betekent voor de lessee. De lessee heeft namelijk het recht op de economische voordelen die met het gebruik van het actief gepaard gaan. Bovendien zijn de te betalen leasetermijnen een betrouwbare schatting van de waarde van dit gebruiksrecht. In geval van de 'risks en rewards'-benadering was deze lease geclassificeerd als een operational lease en had derhalve geen activering bij de lessee mogen plaatsvinden ${ }^{3}$.

De leasetermijnen bestaan uit een aflossingsgedeelte en een interestgedeelte. In navolgend schema is aangegeven hoe groot deze delen in de verschillende jaren van de leaseperiode zijn: 


\begin{tabular}{|l|l|l|l|l|}
\hline Jaar & Schuld 1/1 & Termijn & Interest (10\%) & Aflossing \\
\hline Jaar 1 & $50.000,00$ & $13.189,87$ & $5.000,00$ & $8.189,87$ \\
\hline Jaar 2 & $41.810,13$ & $13.189,87$ & $4.181,01$ & $9.008,86$ \\
\hline Jaar 3 & $32.801,27$ & $13.189,87$ & $3.280,13$ & $9.909,74$ \\
\hline Jaar 4 & $22.891,53$ & $13.189,87$ & $2.289,15$ & $10.900,72$ \\
\hline Jaar 5 & $11.990,81$ & $13.189,87$ & $1.199,08$ & $11.990,79$ \\
\hline Jaar 6 & 0 & & & \\
\hline
\end{tabular}

De situatie aan het eind van jaar 1, na het betalen van de eerste leasetermijn:

\begin{tabular}{r|r|r}
\hline $\begin{array}{r}\text { Balans Lessor (in euro) } \\
\text { Restwaarde } \\
\text { geleaste machines }\end{array}$ & $\begin{array}{r}\text { Balans Lessee (in euro) } \\
\text { Geleaste activa }\end{array}$ & $\begin{array}{l}\text { Leasever- } \\
\text { plichtingen } \\
40.000,00\end{array}$ \\
$\begin{array}{r}\text { Leasedebiteuren } \\
41.810,13\end{array}$ & Bank 13.189,87 \\
Bank $13.189,87$ & & \\
\end{tabular}

\begin{tabular}{|c|c|c|}
\hline \multicolumn{2}{|c|}{$\begin{array}{l}\text { Resultatenrekening } \\
\text { Lessor (in euro) }\end{array}$} & $\begin{array}{l}\text { Resultatenrekenin } \\
\text { Lessee (in euro) }\end{array}$ \\
\hline $\begin{array}{l}\text { Incidenteel } \\
\text { verlies }\end{array}$ & $\begin{array}{l}\text { Interest- } \\
\text { opbrengsten }\end{array}$ & $\begin{array}{l}\text { Interest- } \\
\text { kosten }\end{array}$ \\
\hline 5000,00 & $5.000,00$ & $\begin{array}{l}5.000,00 \\
\text { Afschrijvings- } \\
\text { kosten } \\
\quad 10.000,00\end{array}$ \\
\hline
\end{tabular}

De lessor heeft te maken gehad met een incidenteel verlies van 5.000 euro, omdat de verwachte levensduur van zijn machine met een halfjaar is gereduceerd. De lessor heeft van de lessee een betaling gehad van $13.189,87$ euro, waarvan 5.000 euro interestopbrengsten waren en $8.189,87$ euro het aflossingsgedeelte bedroeg. De lessee heeft lineair afgeschreven over het geleaste actief (10.000 euro).

De situatie direct na afloop van het leasecontract, aan het eind van jaar 5:

\begin{tabular}{|c|c|c|c|}
\hline \multicolumn{2}{|c|}{ Balans Lessor (in euro) } & \multicolumn{2}{|c|}{ Balans Lessee (in euro) } \\
\hline $\begin{array}{l}\text { machines } \\
\qquad 25.000,00\end{array}$ & & & Bank $65.949,35$ \\
\hline Bank $65.949,35$ & & & \\
\hline \multirow{2}{*}{\multicolumn{2}{|c|}{$\begin{array}{l}\text { Resultatenrekening } \\
\text { Lessor (in euro) }\end{array}$}} & \multirow{2}{*}{\multicolumn{2}{|c|}{$\begin{array}{l}\text { Resultatenrekening } \\
\text { Lessee (in euro) }\end{array}$}} \\
\hline & & & \\
\hline & $\begin{array}{l}\text { Interest- } \\
\text { opbrengsten } \\
1.199,08\end{array}$ & $\begin{array}{l}\text { Interestkosten } \\
1.199,08 \\
\text { Afschrijvings- } \\
\text { kosten } 10.000,00\end{array}$ & \\
\hline
\end{tabular}

De lessor heeft in totaal 65.949,35 euro (5 leasetermijnen van 13.189.87 euro) ontvangen van de lessee. Het geleaste actief is overgegaan van de lessee naar de lessor en wordt derhalve nog slechts geactiveerd bij de lessor.

\section{Toetsing aan het Stramien}

De discussie over de verwerking van leasecontracten in de jaarrekening concentreert zich op de twee hiervoor genoemde benaderingen. Om een keuze voor één van de twee verwerkingsmethoden te maken gebruiken wij het Stramien als toetsingskader. Het doel van het Stramien is om te dienen als hulpmiddel bij het ontwikkelen van toekomstige en het herzien van bestaande verslaggevingsstandaarden. Het Stramien wordt voor dit doel internationaal veelvuldig gebruikt en is daarom ook bij dit probleem in de externe verslaggeving een logische keuze. Bovendien kan het gebruik van het Stramien als toetsingskader ook leiden tot de internationale harmonisatie van verslaggevingsregels met betrekking tot leasing.

De 'asset en liability'-benadering is gebaseerd op het Stramien. Alle rechten en verplichtingen die op basis van leasecontracten ontstaan, worden getoetst aan het Stramien. Indien de rechten en verplichtingen overeenstemmen met de definities van activa respectievelijk passiva en met de verwerkingscriteria die daarbij horen, zullen de rechten en verplichtingen in de balans worden opgenomen. Kortom, de 'asset en liability'-benadering sluit aan bij het Stramien.

De in paragraaf 2 besproken 'risks en rewards'benadering sluit niet aan bij het Stramien. Dit blijkt vooral uit de verwerking van operational leasecontracten in de jaarrekening. In geval van een operational lease van een actief verwerft een lessee door middel van het afsluiten van een leasecontract het recht om een actief voor een deel van zijn economische levensduur (gedurende de contractsduur) te gebruiken en op deze manier de verwachte economische voordelen die met het gebruik gepaard gaan. Hiertegenover staat de verplichting die de lessee op zich neemt om voor dit recht een bedrag of een serie bedragen te betalen. 
Het hiervoor genoemde recht en de bijbehorende verplichting komen overeen met de definitie van activa en passiva in het Stramien. Het maakt dus geen verschil of het contract van toepassing is op de gehele levensduur van het actief dan wel voor slechts een deel van de levensduur van het actief. Naar analogie bij financial leasing, zou ook in geval van operational leasing vervolgens verwerking van het gebruiksrecht en de leasetermijnen op de activa- respectievelijk passivazijde van de balans moeten plaatsvinden.

\section{Extra afspraken in leasecontracten}

In het voorafgaande zijn slechts de meest standaard leasecontracten aan bod gekomen. Er zijn echter nog vele andere soorten afspraken binnen leasecontracten mogelijk. Deze afspraken kunnen gevolgen hebben voor de verwerking en waardering van leasecontracten in de jaarrekening. In deze paragraaf komen verschillende afspraken binnen leasecontracten aan de orde, namelijk extra opties in het leasecontract en contingente leasetermijnen ${ }^{4}$.

\subsection{Extra opties in leasecontracten}

Leasecontracten bevatten vaak extra opties, waaruit de lessee de mogelijkheid heeft om een keuze te maken. Zo kunnen leasecontracten de mogelijkheid voor de lessee bevatten om op een bepaald moment tijdens de leaseperiode het contract op te zeggen, of het contract te verlengen.

Binnen de huidige 'risks en rewards'-benadering spelen dergelijke opties een belangrijke rol. Een verlengingsoptie beïnvloedt namelijk de looptijd van het leasecontract. De looptijd van het leasecontract is vervolgens weer een belangrijk indicatiecriterium bij de classificatie van het leasecontract als operational dan wel financial lease en dus bij de bepaling hoe het leasecontract in de jaarrekening dient te worden verwerkt. Lessees proberen leasecontracten vaak zodanig op te stellen dat de verlengingsopties leiden tot een classificatie van het leasecontract als operational lease. Een kwalitatieve toetsing van de verlengingsopties uit het leasecontract zou in deze situatie dergelijke ontduikingsmogelijkheden in de praktijk moeten verhinderen. Voor de waardering van leasecontracten in de jaarrekening spelen deze opties bij de 'risks en rewards'-benadering verder geen rol, omdat bij de 'risks en rewards'benadering de activering en passivering van de financial lease verder beperkt blijft tot waardering tegen de contante waarde van de leasetermijnen.

Bij de 'asset en liability'-benadering daarentegen spelen deze opties een andere rol. Deze opties zijn namelijk rechten voor de lessee en nieuwe rechten zouden op basis van het Stramien tot nieuwe activeringen op de balans kunnen leiden. Volgens de 'asset en liability'-benadering vormen de genoemde rechten activa, indien de rechten passen binnen de definitie en de verwerkingscriteria van activa in het Stramien. Indien de optie aan het begin van de leaseperiode een significante waarde heeft, dient de optie apart van het gebruiksrecht van het geleaste actief, door de lessee in de balans te worden verwerkt. Deze significante waarde moet dan wel betrouwbaar kunnen worden vastgesteld. Een manier om deze waarde te bepalen is het vergelijken van de leasetermijnen van een leasecontract met zo'n optie, met de leasetermijnen van eenzelfde leasecontract, maar dan zonder zo'n optie.

Indien de extra optie een keuze betreft voor de lessee om de lease voort te zetten dan wel te beëindigen, dan speelt er bij deze optie nog een andere kwestie met betrekking tot de externe verslaggeving. Er dient namelijk besloten te worden of de te betalen leasetermijnen en het gebruiksrecht tot het moment waarop de keuze in verband met eventuele verlenging dient te worden gemaakt, dan wel tot het moment dat het contract inclusief de verlengingsperiode doorloopt, op de balans verwerkt dienen te worden. Indien er sprake is van een reële keuze tussen verlenging dan wel beëindiging van het leasecontract, dan is de waarschijnlijkheid van het overgaan van economische voordelen, zoals de verwerkingscriteria in het Stramien vereisen, nog te beperkt om rechten en verplichtingen met betrekking tot de verdere looptijd van de lease te activeren dan wel te passiveren. Rechten en verplichtingen uit het leasecontract dienen in dit geval tot het moment van de verlengingsoptie in de balans te worden verwerkt.

Indien de lessee en de lessor een contract afsluiten met daarin een reële mogelijkheid voor de lessee om de lease op een bepaald moment te beëindigen dan wel te verlengen, dan heeft de lessee goed onderhandeld. De lessee heeft namelijk de financiële flexibiliteit van haar onderneming vergroot. Zonder een dergelijke optie zou de lessee namelijk vastzitten aan een langere leaseperiode dan nu het geval is, de lessee kan dan pas later op economische ontwikkelingen inspelen. Door middel van het toepassen van de hiervoor genoemde 'asset en liability'-benadering blijkt deze financiële flexibiliteit uit de jaarrekening, omdat de leasetermijnen en het gebruiksrecht voor een kortere periode op de balans zijn opgenomen.

De hiervoor genoemde verwerking van verlengingsopties in leasecontracten wordt door de G4+1-organisaties aangehangen, omdat op deze 
manier de financiële flexibiliteit die organisaties hebben bedongen goed uit de jaarrekening blijkt.

Deze benadering biedt naar onze mening echter de mogelijkheid voor bedrijven om leasecontracten af te sluiten waarbij de waarschijnlijkheid dat de leasecontracten worden verlengd door de lessee zeer hoog is. Dit kan bijvoorbeeld door als lessor een hoge boete van de lessee te eisen indien de lessee voor beëindiging van het contract kiest. Het is in deze situatie zeer waarschijnlijk dat ook na het moment van de verlengingsoptie economische voordelen van de lessee naar de lessor zullen vloeien. Leasecontracten met verlengingsopties dienen derhalve kwalitatief te worden getoetst op de waarschijnlijkheid van verlenging. Indien die waarschijnlijkheid, bijvoorbeeld door een boeteclausule, zeer hoog is, dient het leasecontract voor de volledige contractsduur, dus inclusief de verlengingsperiode, te worden verwerkt. Het argument van de G4+1-organisaties dat de financiële flexibiliteit bij deze verwerkingswijze niet uit de jaarrekening blijkt, gaat in deze situatie niet op. Leasecontracten waarbij voortijdige beëindiging van het leasecontract zeer onwaarschijnlijk is, vormen namelijk geen contracten met flexibiliteit. Deze contracten zijn vergelijkbaar met contracten zonder verlengingsoptie en dienen derhalve op dezelfde manier te worden verwerkt.

De hiervoor genoemde problematiek met betrekking tot de verwerking van leasecontracten met een verlengingsoptie bij de lessee speelt ook bij de lessor. De lessor zal bij leasecontracten met een reële verlengingsoptie de vordering op de lessee in de vorm van te betalen leasetermijnen tot het moment dat de lessee de lease kan verlengen op zijn balans kunnen verwerken. Indien opzegging van de lease echter bijvoorbeeld door middel van een hoge boeteclausule niet meer waarschijnlijk is, zal de lessor de vordering tot het eind van de lease inclusief verlengingsperiode moeten activeren.

\subsection{Leasecontracten met contingente lease- termijnen}

In sommige leasecontracten worden contingente leasetermijnen overeengekomen. Contingente leasecontracten zijn leasecontracten waarin de te betalen leasetermijnen niet helemaal vaststaan. Een gedeelte van de leasetermijn zal afhankelijk zijn van bepaalde onzekere toekomstige gebeurtenissen. Er bestaan drie categorieën contingente leasetermijnen, te weten:

1 De leasetermijnen variëren met de mate waarin het actief wordt gebruikt.

2 De leasetermijnen zijn afhankelijk van de winst of de omzet die de lessee met het geleaste actief behaalt, er wordt dan een percentage overeengekomen.

3 De leasetermijnen zijn afhankelijk van de ontwikkelingen in de marktprijs.

De eerste categorie van contingente leasetermijnen vertoont dezelfde eigenschappen als een verlengingsoptie. De lessee heeft bij beide de mogelijkheid om meer gebruik te maken van het geleaste actief. De verwerking zal dan ook op dezelfde manier geschieden. Categorieën 2 en 3 moeten echter meer worden gezien als een verplichting voor de lessee om een nog onzeker bedrag aan de lessor te betalen.

In de 'risks en rewards'-benadering wordt de variabele leasetermijn niet doorberekend in de minimumleasetermijnen, die de basis vormen voor de classificatie operational dan wel financial lease. Bij deze benadering wordt de variabele leasetermijn ook niet opgenomen op de balans indien een lessee het actief bij een financial lease activeert.

\section{Ad 1}

In de 'asset en liability'-benadering hebben de variabele leasetermijnen een direct effect op de waardering van activa en passiva die onder leasecontracten ontstaan. Wanneer in een leasecontract wordt afgesproken dat de leasetermijn varieert met de mate waarin het actief wordt gebruikt, dan heeft dat wanneer het afgesproken variabele tarief overeenkomt met de waarde die in het economisch verkeer aan het extra gebruik zou worden toegerekend, geen effect voor de lessee. De waarde van de optie is in dit geval nihil. Het verschil met de 'risks en rewards'-benadering komt naar voren bij de verwerking van activa bij de lessor. De lessor heeft op het moment dat de lessee niet over de afgesproken limiet heengaat geen onvoorwaardelijk recht om gebruiksafhankelijke betalingen te ontvangen van de lessee. De lessor dient bij het afsluiten van een leasecontract de te ontvangen leasetermijnen van leasecontracten met contingente leasetermijnen te activeren, het ontvangen van extra gelden door een hoger gebruik dient in de resultatenrekening te worden verwerkt. Indien het extra gebruik nadelige gevolgen voor de verwachte restwaarde van het geleaste actief heeft, dient het actief met deze waardevermindering te worden afgeboekt.

\section{Ad 2}

Bij leasecontracten waarin een variabel bedrag is opgenomen dat afhankelijk is van de te behalen omzet, dient een vergelijking te worden gemaakt met leasecontracten waarin deze variabele niet opgenomen is. Leasecontracten zonder variabele zullen een hogere leasetermijn hebben. Het verschil tussen de leasetermijnen van beide contrac- 
ten dient bij de verwerking van het leasecontract met deze contingente leasetermijnen op de balans te worden opgenomen.

\section{Ad 3}

In sommige leasecontracten wordt afgesproken dat er periodiek wordt beoordeeld of de in het leasecontract afgesproken leasetermijnen nog overeenkomen met de huidige marktprijs. Er kan hier sprake zijn van een jaarlijkse evaluatie maar ook een evaluatie eens in de vijf jaar is een mogelijkheid. De leasetermijnen van een langlopend contract waarin de lessor de mogelijkheid heeft om op een vooraf vastgesteld tijdstip de leasetermijn te verhogen indien de marktprijs hiertoe aanleiding geeft, zullen in beginsel lager liggen dan de leasetermijnen van een overeenkomstig leasecontract zonder deze mogelijkheid. De contante waarde van de leasetermijnen van een contract met mogelijkheid tot prijsverandering zal echter niet leiden tot een betrouwbare weergave van de waarde van de uit het contract voortvloeiende activa en passiva. Dit vindt zijn oorzaak in de onzekerheid die de ontwikkeling van de marktprijs met zich meebrengt. Binnen de 'asset en liability'-benadering wordt de lessee geacht als volgt te handelen: bij het afsluiten van het leasecontract moet de lessee een actief en passief opnemen tegen de contante waarde van de zo goed mogelijk geschatte werkelijk te betalen leasetermijnen. Bovendien dient volgens de G4+1-organisaties bij leasecontracten met prijsafhankelijke leasetermijnen elk jaar de geschatte waarde van het geleaste actief opnieuw te worden vastgesteld, ongeacht het feit of de marktprijs dat jaar is veranderd.

De hiervoor genoemde benadering van G4+1organisaties is naar onze mening echter niet volledig in lijn met het Stramien. Lessees hebben namelijk voordat een marktprijsstijging heeft plaatsgevonden en de lessor deze prijsstijging aan de lessee doorberekent, geen verplichting om de hogere leasetermijnen op de balans te verwerken. De waarschijnlijkheid dat in de toekomst economische voordelen van de lessee naar de lessor zullen toevloeien is namelijk nog beperkt en bovendien is de waarde van deze leasetermijnen nog niet betrouwbaar vast te stellen. De passivering van de verhoging van de leasetermijnen en het bijbehorende opboeken van het toegenomen actief, dienen volgens het Stramien dan ook pas plaats te vinden indien de hogere marktprijs daadwerkelijk aan de lessee wordt doorberekend.

\section{Gevolgen voor de praktijk}

Indien wet- en regelgevende instanties de verslag- gevingsstandaarden in verband met de verwerking van leasecontracten in de jaarrekening veranderen van de 'risks en rewards'-benadering in de 'asset en liability'-benadering, zal dit grote gevolgen hebben voor de praktijk. Een belangrijke reden voor bedrijven om gebruik te maken van leasing is namelijk de mogelijkheid van off-balance sheetfinanciering van activa, die de 'risks en rewards'benadering biedt. Bij invoering van de 'asset en liability'-benadering zal deze mogelijkheid verdwijnen, omdat alle rechten en plichten die op basis van het leasecontract ontstaan in beginsel in de jaarrekening zullen worden verwerkt. Het effect van het opnemen van operational leasecontracten in de jaarrekening op verschillende kengetallen, zoals de current ratio, winstmarges en het rendement op het eigen vermogen, wordt uitvoerig besproken in het artikel van Beattie, Edwards en Goodacre (1998). Het verdwijnen van de mogelijkheid van off-balance sheet-financiering zal leiden tot een verminderde vraag naar leasecontracten. Deze aanpassing zal voor leasemaatschappijen een groot nadeel betekenen. De leasemaatschappijen kunnen op basis van de huidige regelgeving echter profiteren van de mogelijkheid van off-balance sheet-financiering. Omdat de regelgeving nooit een bepaalde bedrijfstak een concurrentievoordeel mag geven, in dit geval aan de leasemaatschappijen ten opzichte van verkopers van vaste activa, zal een aanpassing van de regelgeving in verband met de verwerking van leasecontracten in de jaarrekening geen onterecht nadeel voor de leasemaatschappijen betekenen.

Regelgeving is daarentegen ook niet bedoeld om bedrijfstakken in de problemen te brengen. Handhaving van de 'risks en rewards'-benadering zou een bescherming van de leasemaatschappijen betekenen. De 'risks en rewards'-benadering sluit echter niet aan bij het Stramien. Dus indien de regelgevende instanties het Stramien willen handhaven, dan zal de keuze voor de 'asset en liability'benadering moeten worden gemaakt.

Een gevolg van het toepassen van de 'asset en liability'-benadering zou kunnen zijn dat er meer en meer leasecontracten met allerlei verlengingsopties worden afgesloten. Op deze manier zou de verwerking van rechten en leaseverplichtingen op het leasecontract tot een minimum beperkt kunnen worden. Wanneer er gebruik wordt gemaakt van een kwalitatieve toets, van de waarschijnlijkheid dat de verlengingsopties ook daadwerkelijk zullen worden uitgeoefend, dan zal ook deze mogelijkheid tot (gedeeltelijke) off-balance sheetfinanciering niet meer mogelijk zijn indien er geen sprake is van een voortdurend opzegbaar leasecontract. 


\section{Samenvatting en conclusie}

In dit artikel zijn de 'risks en rewards'-benadering en de 'asset en liability'-benadering aan de orde geweest. Bovendien zijn voor beide benaderingen de gevolgen van enkele extra afspraken in leasecontracten voor de verslaggeving besproken. De beide benaderingen hebben een ander uitgangspunt voor de verwerking van leasecontracten in de jaarrekening. Het uitgangspunt van de 'risks en rewards'-benadering is de bepaling of de risico's en voordelen in verband met het in eigendom hebben van het actief voor de lessor dan wel voor de lessee zijn. Op basis van deze verdeling van risico's en voordelen wordt onderscheid gemaakt tussen operational en financial leases. De lessee verwerkt de lease alleen in het geval van een financial lease op de balans. Het uitgangspunt van de 'asset en liability'-benadering wordt de verwerking van leasecontracten in de jaarrekening direct gekoppeld aan het Stramien. Het onderscheid tussen financial en operational leasing wordt losgelaten. De rechten en verplichtingen, die ontstaan op basis van een leasecontract, dienen als basis voor de verwerking van afgesloten leasecontracten in de jaarrekening van zowel de lessor als de lessee. Ook komen de traditionele operational leasecontracten nu voor verwerking in de balans van de lessee in aanmerking.

In paragraaf 5 is gebleken dat binnen leasecontracten vaak extra afspraken worden gemaakt. Binnen de 'risks en rewards'-benadering komen de waarde en de gevolgen van de gemaakte afspraken niet tot uitdrukking in de jaarrekening van de lessor en de lessee. Gebruikers van de jaarrekening kunnen dan ook geen getrouw beeld krijgen van de feitelijke financiële situatie van de lessor dan wel de lessee. Binnen de 'asset en liability'-benadering is de situatie echter geheel anders. Gemaakte extra afspraken kunnen binnen deze benadering enerzijds niet leiden tot verschil in het al dan niet opnemen van het leasecontract in de jaarrekening van de lessee. Anderzijds komen de gemaakte afspraken, indien zij leiden tot bepaalde rechten of verplichtingen voor de lessee of de lessor, in de balans van de lessee dan wel lessor tot uitdrukking. Op deze manier geeft de jaarrekening een getrouw beeld van de financiële positie van de lessor dan wel de lessee, gebaseerd op de rechten en verplichtingen die beiden hebben. Ook indien lessors of lessees op basis van afgesloten leasecontracten hun financiële flexibiliteit hebben vergroot, blijkt dit uit de jaarrekening. In het geval van extra afspraken die alleen worden gemaakt om de activering van rechten en passivering van verplichtingen te beperken, dient kwalitatieve toetsing van dergelijke afspraken misbruik te voorkomen.

Uit de vergelijking tussen de 'risks en rewards'-benadering en de 'asset en liability'benadering komen verschillende voordelen van de 'asset en liability'-benadering naar voren. Ten eerste worden binnen deze benadering alle leasecontracten op dezelfde consistente en duidelijke manier verwerkt, gebaseerd op het internationaal geaccepteerde Stramien. Ten tweede worden via deze benadering alle rechten en verplichtingen van de lessee en de lessor in de jaarrekening verwerkt, zodat een getrouwer beeld van de werkelijkheid wordt gegeven. Ten derde kan door de aansluiting op het Stramien beter en consistenter worden omgegaan met moderne, complexe afspraken in leasecontracten.

\section{LITERAT U UR}

Beattie, V., K. Edwards en A. Goodacre, (1998), The Impact of Constructive Lease Capitalisation on Key Accounting Ratios, Accounting and Business Research, volume 28, number 4, pp. 233-254.

Deloitte \& Touche, Vereniging VNO-NCW, (2000), Internationale verslaggevingsregels. Wat betekenen ze voor Nederlandse ondernemingen?, Rotterdam/ Den Haag, pp. 71-74.

G4+1 (Australian Accounting Standards Board; Canadian Accounting Standards Board; International Accounting Standards Committee; United Kingdom Accounting Standards Board; United States Financial Accounting Standards Board), McGregor, W. (principal author), (1996), Accounting for leases: a new approach. Recognition by lessees of assets and liabilities arising under lease contracts, Financial Accounting Series, No. 163-A.

G4+1 (Australian Accounting Standards Board; Canadian Accounting Standards Board; International Accounting Standards Committee; New Zealand Financial Reporting Standards Board, United Kingdom Accounting Standards Board; United States Financial Accounting Standards Board), (2000), Discussion paper: Leases: implementation of a new approach.

International Accounting Standards Committee, (1997), E56: Leases, Exposure draft voorafgaand aan IAS 17.

International Accounting Standards Committee, (1997), IAS 17 (revised), Leases.

Klaassen, J., (1997), Algemene Grondslagen van externe verslaggeving, in: M.N. Hoogendoorn, J. Klaassen, F. Krens (redactie), Externe verslaggeving in theorie en praktijk, tweede druk, Delwel Uitgeverij B.V., 's-Gravenhage. 
Laan Bouma, R.P.B. van der, (1997), Leasecontracten, in M.N. Hoogendoorn, J. Klaassen, F. Krens (redactie), Externe verslaggeving in theorie en praktijk, tweede druk, Delwel Uitgeverij B.V., 's-Gravenhage.

Raad voor de Jaarverslaggeving, (vanaf 1990), Stramien voor de opstelling en vormgeving van jaarrekeningen, uit Richtlijnen voor de Jaarverslaggeving vanaf 1990, onderdeel S.

Tweedie, D., (1999), (L.A.G.M. van Lent, redactionele bewerking), IOSCO Endorsement... and beyond, Maandblad voor Accountancy en Bedriffseconomie, 73/9, pp. 475-480.

Wouterson, J.M.en G.H. Zevenboom, (1995), Leasing, in M.N. Hoogendoorn, J.A.G.M. Koevoets,

R.G.A. Vergoossen, Het jaar verslagen, Onderzoek jaarverslaggeving 1995, NIVRA-geschriften 66, Kluwer Bedrijfswetenschappen, Deventer, pp. 89-105.

\section{NOTEN}

1 De hierna volgende subparagrafen 'definiëring', 'verwerking', en 'waardering' zijn gebaseerd op het rapport 'Leases: Implementation of a New Approach' (2000, G4+1-Organisatie).

2 In de balansen die in dit voorbeeld worden gebruikt, zullen alleen de posten en bedragen die in verband met het leasecontract van belang zijn, worden aangegeven.

3 In het geval er in het voorbeeld sprake zou zijn geweest van financial lease, zou het verschil tussen de 'risks en rewards'-benadering en de 'asset en liability' benadering naar voren komen bij de activering van de restwaarde van het leaseobject door de lessor. Binnen de 'risks en rewards'-benadering wordt de restwaarde niet geactiveerd, omdat bij een financial leasecontract het leaseobject wordt geacht geheel over te gaan van de lessor naar de lessee.

4 Deze paragraaf is gebaseerd op de hoofdstukken 4 en 11 uit het rapport 'Leases: Implementation of a New Approach' (2000, G4+1-Organisatie). 